\title{
OTENTISITAS KOMUNIKATOR DAN MOTIVASI MENULIS MAHASISWA DI MEDIA SOSIAL
}

\author{
COMMUNICATOR AUTHENTICITY AND WRITING MOTIVATION OF \\ UNIVERSITY STUDENTS ON SOCIAL MEDIUM
}

\author{
Zainurrahman \\ Sekolah Tinggi Keguruan dan Ilmu Pendidikan, Kie Raha Ternate \\ Jalan STKIP, Jambula-Sasa, Kota Ternate Selatan
}

Tlp./Faks. (0921) 3120022

\begin{abstract}
Abstrak
Penelitian ini dilakukan untuk memahami hal-hal yang memicu motivasi menulis mahasiswa di media sosial, yang oleh suatu proyek (writing matrix) disebut otentisitas komunikator yang menyediakan interaksi tekstual yang otentik. Frekuensi aktivitas menulis mahasiswa di media sosial merupakan suatu fenomena yang mengagumkan jika dibandingkan dengan aktivitas menulis mereka di ruang-ruang kelas. Penelitian kualitatif deskriptif ini menggunakan angket sebagai instrumen pengumpulan data, yang selanjutnya dianalisis dengan menggunakan teori emosi, motivasi, dan media pembelajaran terkomputerisasi. Penelitian ini menyimpulkan bahwa otentisitas komunikator bukanlah pemicu utama motivasi menulis mahasiswa di media-media sosial, melainkan nilai dan makna yang diberikan oleh mahasiswa terhadap media-media sosial itu sendiri. Fitur, kemudahan, kepuasan emosional, merupakan pemicu-pemicu utama yang terjaring dalam data penelitian ini. Signifikansi akademik dari penelitian ini menunjukkan adanya peluang bagi para pengasuh mata kuliah menulis (writing) untuk meningkatkan motivasi menulis mahasiswa mereka di ruang-ruang kelas atau dalam konteks akademik lainnya.
\end{abstract}

Kata kunci: motivasi, menulis, media sosial, otentisitas komunikator

\begin{abstract}
This research is accomplished to understand the triggers of the university students' motivation in writing through social medium networks which is suspected by writing-matrix project, it is wellknown as 'communicator authenticity' which provides an authentic textual interaction. It is realized that the frequency of students' writing activity on social media is a wonderful phenomena if it is compared to their writing activity in the classroom. This qualitative descriptive research used questionnaire as the instrument in collecting the data, which are then analyzed by applying theory of emotion, motivation, and computerized learning media. This research concluded that communicator authenticity is not the only trigger of students' motivation to write on social medium, but the value and the meaning given by the students toward the social media itself that play an important role. Features, easiness, and emotional fulfillment to write are the other triggers which motivate students to write frequently on the social media. The academic significance of this research shows an opportunity for the lecturer to increase students writing motivation in the classroom-based writing activity or in the other academic contexts.
\end{abstract}

Keywords: motivation, writing, social media, communicator authenticity

\section{Pendahluluan}

Salah satu masalah klasik yang awet di dalam dunia pendidikan tinggi di berbagai strata adalah rendahnya motivasi menulis para mahasiswa. Hal ini dengan mudah dapat kita amati dari rendahnya frekuensi menulis mahasiswa dan meningkatnya jumlah tugas akhir yang tidak orisinil dari tingkat skripsi 
hingga disertasi. Selain itu, fenomena plagiarisme yang memprihatinkan juga seolaholah menjadi salah satu episode tragis perguruan tinggi yang ditayangkan berulangulang; tentu saja sudah banyak pendidik (dosen) yang berupaya keras untuk melakukan perubahan skenario episode ini. Berbagai upaya pembinaan yang dilakukan dengan berbagai metode telah diselenggarakan, namun persoalan akademik ini masih sering terpikirkan sebagai solusi bagi sejumlah besar mahasiswa.

Tidak sedikit mahasiswa yang menganggap menulis sebagai salah satu tugas berat bagi mereka dan ini disebabkan oleh minimnya kemampuan menulis mereka. Upaya dosen untuk meningkatkan kemampuan mereka dengan cara memberikan koreksi (teacher feedback) seringkali mendapatkan porsi kecil perhatian mahasiswa (Lee, 2008:1) dan bahkan tidak sedikit dosen yang tidak membaca, apalagi mengoreksi, tulisan mahasiswa karena terkendala jumlah teks dan waktu yang tersedia. Para dosen dapat melakukan upaya lain untuk mengatasi hal ini yakni dengan menerapkan koreksi teman sebaya (peer feedback) yang diharapkan bisa menjadi alternatif terbaik upaya peningkatan kemampuan menulis mahasiswa dan masalah lain pun bermunculan. Keterbatasan pengetahuan mahasiswa kerap kali menjadi sebab munculnya salah koreksi (Williams, 2005:97) dan bahkan koreksi teman sebaya bisa menjadi sebab iritasi sosial antarsesama mahasiswa (Hong, 2006:94). Berbagai upaya yang dilakukan oleh dosen untuk meningkatkan kemampuan menulis mahasiswa mengalami berbagai hambatan karena seringkali dosen tidak memperhatikan motivasi yang melatarbelakangi proses menulis itu sendiri. Dengan demikian, mahasiswa mungkin tetap melaksanakan tugas sesuai dengan arahan dosen, namun tentu saja tujuan mereka adalah penyelesaian mata kuliah semata. Hal ini dapat kita lihat dari rendahnya produk tulisan mereka di luar konteks perkuliahan.

Melihat fenomena yang cukup memprihatinkan ini, kita kemudian berasumsi bahwa motivasi mahasiswa untuk menulis sangat minim; demikian pula motivasi membaca mereka. Hal ini logis karena mahasiswa hanya akan mampu menulis jika mereka banyak membaca.

Namun ada fakta unik dalam konteks ini. Meskipun kita berasumsi demikian, dalam keseharian kita, kita bisa mengamati bagaimana mahasiswa rela menghabiskan waktu berjamjam untuk berinteraksi secara tertulis di media sosial. Lebih dari itu, salah satu fitur yang ditawarkan oleh perkembangan teknologi berbasis sistem informasi adalah meningkatnya frekuensi interaksi tertulis dari skala paling kecil yakni SMS (short message service) hingga surel atau blog.

Salah satu media komunikasi sosial yang paling menyita perhatian dan energi mahasiswa dalam aktivitas baca tulis adalah facebook. Tidak ada perbedaan signifikan antara menulis artikel dan memperbaharui status di facebook. Tidak ada perbedaan signifikan antara memberikan feedback pada suatu artikel dan mengomentari status relasifacebook.

Minat baca mahasiswa dapat terlihat dari hebatnya ketahanan perhatian mereka dalam melakukan scrolling laman demi laman media sosial. Bahkan, mahasiswa selalu menanti adanya notifikasi komentar atau apresiasi relasi mereka atas status yang mereka perbaharui. Fakta unik ini tidak berhenti sampai disitu saja, satu orang mahasiswa memiliki lebih dari satu akun media sosial. Selain facebook yang hampir menjadi "medsos wajib" bagi mereka, mereka juga memiliki akun medsos lainnya seperti whatsaap, line, talk, dan sebagainya. Uniknya, relasi media sosial yang mereka punya di media-media sosial yang berbeda-beda ini adalah relasi yang sama. Dari sisi ini, kita benar-benar kagum dengan motivasi baca-tulis mereka. Bukankah penting untuk kita pertanyakan motivasi di balik gejala berbahasa yang mengagumkan itu?

Berangkat dari hal-hal yang telah disebutkan di atas, maka peneliti kemudian tertarik melakukan studi sebagaimana judul yang tertera di atas. Penelitian ini mengungkap faktor-faktor yang dapat diidentifikasi sebagai motivasi aktivitas menulis yang mengendap di dalam emosi para mahasiswa. Semestinya, penelitian ini dapat memberikan penyegaran kepada kita semua sebagai pelaku pendidikan bahasa di tanah air terutama berkaitan dengan 
metode dan teknik yang dapat kita terapkan dalam pengajaran menulis.

\section{Kerangka Teori}

Teori utama yang memayungi penelitian ini adalah teori motivasi yang merupakan sub kajian teori emosi yang digagas oleh Fridja dalam Laws of Emotion (Frijda, 1988) serta gagasan motivasi Dickinson (1995) dan Bold (2004). Sementara itu, teori-teori pembelajaran berbasis teknologi sistem informasi turut menopang penelitian ini, di antaranya adalah gagasan-gagasan writingmatrix (Stevens et al, 2008), gagasan eportfolios (Lee, 2008), dan gagasan interaksi berbasis sistem informasi (Pinkman, 2005).

\subsection{Emosi sebagai Sumber Perilaku Menulis}

Adalah suatu hambatan yang paling menantang bagi seorang guru atau dosen yang hendak meningkatkan kemampuan menulis peserta didik tanpa memahami motivasi yang melatarbelakangi hal tersebut. Untuk itu, maka memahami arti motivasi yang sesungguhnya berada di bawah domain emosi merupakan salah satu urgensi. Tidak terkecuali dalam penelitian ini, peneliti melakukan telaah pustaka tentang motivasi dan menemukan link antara motivasi dan emosi yang benar-benar bersifat dependen: motivasi adalah salah satu realisasi emosi.

Emosi adalah salah satu entitas atau produk yang dihasilkan oleh jaringan-jaringan sinaptik yang prosesnya terjadi di dalam otak, khususnya pada sistem limbik yang disebutsebut sebagai emotional processing system (Noback et al, 2005:390) atau sistem pemrosesan emosi. Emosi dan pikiran diciptakan bersama-sama di dalam otak pada region yang berbeda. Meskipun keduanya merupakan kecerdasan yang berbeda, emosi dan pikiran saling memengaruhi antara satu dengan yang lain. Emosi memengaruhi kognisi dan juga memengaruhi tindakan motorik; begitu pula sebaliknya.

Emosi dapat dimengerti sebagai bentuk respon mental terhadap suatu stimulus seperti keadaan, kejadian, situasi, benda, atau orang lain. Respon mental atau emosi yang dialami seseorang terhadap suatu objek sangat dipengaruhi oleh makna yang diberikan terhadap objek tersebut. Sementara itu, makna dari sesuatu tergantung pada kesadaran seseorang akan nilai dari sesuatu itu. Disini, Frijda berteori, ketika makna dari objek tersebut berubah (menurut seseorang) maka emosi terhadap sesuatu itu ikut berubah (Frijda, 1988:350). Dari titik tolak ini, kita bisa melihat bagaimana emosi kita dipengaruhi oleh sistem kognisi kita. Ketika sistem kognisi kita memberikan nilai positif terhadap suatu objek, maka secara bersamaan muncul emosi positif sebagai respon mental kita terhadap objek tersebut. Dengan demikian, batasan antara pikiran dan perasaan, kognisi dan emosi, sangatlah tipis. Batasan tipis ini pun dihilangkan oleh Cacciopo \& Berntson (2007:1353) dengan menyimpulkan bahwa emosi malah merupakan salah satu bentuk kognisi.

Teori-teori atau gagasan-gagasan di atas menjawab pertanyaan peneliti selama bertahuntahun mengasuh mata kuliah menulis (writing) di perguruan tinggi. Maraknya plagiarisme, minimnya motivasi menulis, lakunya bisnis tugas akhir, bukan semata-mata dipengaruhi oleh rendahnya kemampuan menulis itu sendiri, melainkan karena rendahnya nilai yang diberikan oleh mahasiswa terhadap aktivitas menulis itu sendiri. Mayoritas mahasiswa gagal menyadari betapa bernilainya keterampilan menulis dan banyak dosen (termasuk peneliti) gagal menyadarkan mahasiswa tingginya nilai keterampilan menulis di dalam struktur pengalaman dan kehidupan mereka. Nilai minus yang diberikan oleh mahasiswa terhadap aktivitas menulis, jika kirta bersandar pada teori emosi di atas, menurunkan suatu emosi negatif terhadap aktivitas menulis itu sendiri. Singkat kata, penyebabnya bukan pada minimnya kemampuan menulis mahasiswa, melainkan karena rasa keberatan yang merupakan wujud emosi negatif yang dihasilkan dari resepsi kognitif mereka terhadap aktivitas menulis itu sendiri.

Sering kali para mahasiswa dengan penuh rasa keberatan menyelesaikan tugas-tugas mereka karena "termotivasi”" secara negatif oleh dosen seperti rasa khawatir tidak lulus. Bentukbentuk emosi ini pada dasarnya bersifat timerelease yang tidak permanen dan akhirnya pemahaman dan kemampuan mahasiswa dalam 
menulis tidak mengalami perkembangan karena tidak matangnya hubungan sinaptik di dalam otak yang boleh jadi disebabkan oleh kebiasaan-kebiasaan menjiplak yang dilakukan oleh para mahasiswa untuk menyelesaikan tugas menulis. Hal ini terjadi karena goal dari proses yang mereka jalani adalah goal yang ditentukan oleh dosen melalui ancamanancaman yang memicu emosi negatif seperti rasa takut, cemas, malu, sedih, dan sebagainya.

Ditinjau dari disiplin ilmu psikologi kognitif, Isen (dalam Lewis, Jones, \& Barret, 2008:549) menyebutkan, emosi negatif dan emosi positif mempengaruhi aspek kognisi termasuk performa berfikir, belajar, mengingat, fokus, dan pemecahan masalah. Selanjutnya, Isen menyebutkan bahwa orang yang positif secara emosional memiliki strategi berfikir yang lebih fleksibel. Dengan demikian, emosi negatif pada dasarnya menghasilkan kekakuan berfikir yang memengaruhi kemampuan mereka dalam mengambil keputusan atau merespon materi. Memahami hal ini, maka emosi positiflah yang harus dibangun oleh dosen terhadap mahasiswa, khususnya di dalam pembelajaran menulis agar emosi yang terbentuk bukanlah emosi yang bersifat timerelease (untuk sementara waktu demi tujuan singkat) tetapi emosi yang bersifat real-time atau sepanjang masa. Dengan kata lain, emosi positif terhadap aktivitas menulis akan menghasilkan motivasi yang permanen.

\subsection{Emosi sebagai Sumber Motivasi}

Uraian singkat di atas semestinya membuka jalan bagi pemahaman kita tentang emosi sebagai sumber motivasi. Secara etimologis, baik emosi (emotion) maupun motivasi (motivation) berasal dari akar kata yang sama, yakni movere (bahasa Latin) yang berarti bergerak (move). Dari pengertian ini, emosi dan motivasi sama-sama merupakan penggerak atau stimulus yang mendorong seseorang untuk berupaya atau bergerak untuk menuju atau untuk menjauhi suatu tujuan atau suatu objek. Dalam pandangan Bold (2004:11) motivasi, secara esensial, adalah salah satu bentuk emosi. Disebutkan bahwa motivasi adalah suatu kualitas psikologis yang mendorong organisme untuk melakukan suatu tindakan untuk meraih suatu tujuan yang diinginkan. Sementara itu,
Keller (dalam Dickinson, 1995:168) menyatakan bahwa motivasi adalah pilihanpilihan yang dibuat oleh orang-orang untuk mengalami, mendekati, atau menjauhi suatu tujuan atau suatu objek, beserta kualitas upaya yang akan mereka lakukan untuk mencapai hal tersebut. Melengkapi gagasan di atas, Deci, Vallerand, Pelletier \& Ryan (1995:327) mengungkapkan bahwa kebutuhan terhadap tujuan merupakan energi dasar yang menjadi penentu kualitas upaya untuk mendekati atau menjauhi suatu tujuan atau suatu objek. Gagasan-gagasan ini kemudian menciptakan turunan motivasi yang kita kenal dengan istilah motivasi ekstrinsik dan motivasi intrinsik. Dua kategori motivasi ini bersumber dari tujuan suatu aktivitas yang menentukan apakah aktivitas tersebut akan dilakukan atau dicapai, atau akan diabaikan atau dijauhi. Motivasi intrinsik dan ekstrinsik dapat dipahami dari sumber dorongan yang menyebabkan suatu pencapain didekati atau dijauhi (Ryan \& Deci, 2000:60).

Dari uraian di atas, maka kita dapat memahami motivasi yang melatarbelakangi minimnya aktivitas menulis mahasiswa di ruang-ruang kelas, dan tingginya motivasi mereka menulis ketika berinteraksi di media sosial. Akan tetapi, kita perlu mempertimbangkan gagasan-gagasan tentang pemanfaatan media yang relevan dengan aktivitas menulis yang dibahas berikut.

\subsection{Pengaruh Media terhadap Aktivitas Menulis}

Perkembangan teknologi menawarkan sejumlah besar jasa bagi kita khususnya dalam konteks aktivitas menulis. Eksistensi komputer yang menggantikan buku dan pena memberikan kemudahan dan efisiensi dalam menulis. Lebih jauh lagi, media transfer informasi yang kita sebut internet memberikan kita kemudahan besar dalam distribusi dan transaksi informasi yang menembus batas ruang dan waktu. Dengan demikian, media memiliki pengaruh yang amat besar terhadap aktivitas menulis.

Meskipun demikian, masih banyak mahasiswa yang tidak memanfaatkan potensi media untuk menulis secara maksimal. Sebagian besar di antara mereka menyalahgunakan media-media berbasis 
teknologi tersebut. Plagiarisme dapat terjadi dan tumbuh subur di kalangan akademik karena adanya fitur media yang memungkinkan hal tersebut terjadi. Media, karena menawarkan begitu besar manfaat, boleh jadi memiliki sisi negatif dan salah satunya adalah menekan pertumbuhan minat atau motivasi menulis itu sendiri. Mahasiswa tumbuh menjadi pribadipribadi yang tidak orisinal di dalam berkarya; tidak otentik.

Beberapa peneliti kemudian melakukan studi terhadap efektivitas dan efisiensi media, khususnya media sosial, terhadap motivasi menulis. Beberapa di antaranya adalah proyek writingmatrix yang dilakukan oleh Stevens dan rekan-rekannya (2008). Di dalam proyek tersebut, para responden (siswa-siswa) melakukan interaksi tertulis melalui website yang mereka sediakan. Para siswa terhubung melalui jaringan dengan metode yang mereka sebut tagging. Dengan tagging ini, para siswa benar-benar antusias dalam berinteraksi. Dalam laporan mereka, disebutkan bahwa antusiasme menulis siswa meningkat pesat. Salah satu kesimpulan mereka adalah bahwa para siswa atau penulis menyadari komentar otentik dari pembaca yang adalah teman mereka sendiri. Dengan kata lain, otentisitas komunikator atau audiens dalam interaksi berbasis jaringan yang disebut writingmatrix itulah yang menjadi pemicu antusiasme menulis para siswa terutama di media sosial.

Selain kemudahan yang diberikan oleh media terhadap aktivitas menulis, ini merupakan salah satu pengaruh dari media sosial dalam interaksi menulis yang sekaligus menjadi pengaruh yang paling utama.

Selain itu, penggunaan media juga menyediakan peluang terjadinya kolaborasi menulis sebagaimana yang diungkap oleh Urkuhart \& McIver (2005:44). Kita sama-sama memaklumi bahwa kolaborasi dalam menulis menunjang keberhasilan aktivitas menulis itu sendiri yakni dalam bentuk penyempurnaan, pengayaan, atau koreksi terhadap tulisan. Melalui media sosial, para penulis, atau para mahasiswa, sadar atau tidak sadar, mendapatkan dirinya di dalam suatu struktur interaksi kolaboratif. Hal ini juga sesuai dengan prinsip interaksi linguistis (lisan maupun tulisan) yang merupakan interaksi sosial; dan bahkan menulis itu bukan hanya sekedar proses kognitif, tetapi juga proses sosial.

Lee (2008) menggagas proyek yang disebut eportfolios yang menyebutkan pengaruh lain dari pemanfaatan media sosial, yakni kemudahan manajemen dan distribusi tulisan siswa atau mahasiswa. Menurut dia, kemudahan yang ditawarkan oleh media terletak pada ekonomisasi waktu dan energi dalam menyimpan, mengelola, dan mendistribusi tulisan siswa. Singkatnya, Lee merekomendasikan pemanfaatan media dari aspek aksesibilitas.

Dengan demikian, maka media sosial yang selama ini dimanfaatkan oleh para mahasiswa dalam interaksi tertulis mereka setidaknya memiliki tiga pengaruh terhadap motivasi menulis mereka di antaranya adalah:

- Media sosial menyediakan penulis dan pembaca yang otentik dan ini memicu motivasi mereka untuk menulis.

- Media sosial menyediakan peluang berkolaborasi dalam membangun dan menghubungkan ide melalui komentar atau feedback yang diberikan secara online.

- Media sosial menyediakan aksesibilitas informasi yang berkaitan dengan tulisan, baik tulisan mereka sendiri maupun tulisan orang lain yang merupakan relasi media sosial mereka.

Teori-teori yang dijelaskan di atas memberikan kita peluang untuk berasumsi tentang pemicu-pemicu motivasi mahasiswa dalam berinteraksi tertulis dengan menggunakan media sosial. Sebaliknya, teoriteori di atas juga memberikan kita peluang berasumsi tentang hal-hal yang melatarbelakangi minimnya motivasi menulis mahasiswa di ruang-ruang kelas bahkan pada tingkatan tugas akhir, skripsi, tesis, dan disertasi.

Ada kemungkinan para mahasiswa beranggapan bahwa tulisan mereka tidak dibaca. Di satu sisi mereka menganggap membangun teks dengan kemampuan kognitif yang mereka miliki adalah suatu hal yang terlalu menantang bagi mereka. Di sisi lain, ada kemungkinan mereka beranggapan bahwa menulis dengan media lain selain media sosial menghambat mereka untuk mengakses informasi tulisan mereka sendiri atau tulisan 
teman mereka. Namun ini adalah anggapananggapan semata yang harus diuji dalam suatu penelitian yang ketat.

Melalui data yang dijaring dalam penelitian ini, berdasarkan teori-teori yang telah digagas sebelumnya, penelitian ini berupaya untuk mengungkap pemicu-pemicu motivasi menulis mahasiswa di media sosial khususnya yang berhubungan dengan otentisitas audiens.

\section{Metode Penelitian}

Penelitian ini merupakan suatu survei yang mengakomodasi metode kualitatif deskriptif. Meskipun demikian, penggunaan tabel dalam menyajikan data dan juga statistik deskriptif dalam interpretasi data dan penarikan kesimpulan juga dapat ditemui dalam penelitian ini.

Data penelitian ini dijaring melalui angket untuk mengukur sikap dan juga menjaring informasi yang relevan dengan aktivitas menulis dengan menggunakan media sosial, khususnya facebook. Data-data ini akan dikelompokkan dan akan mengalami reduksi pada bagian-bagian tertentu yang dianggap tidak relevan. Untuk menganalisa data, statistik deskriptif dan metode normatif layak digunakan dalam penelitian ini dimana data-data dicocokkan dengan teori-teori atau gagasangagasan yang telah dipaparkan pada bagian sebelumnya. Langkah-langkah analisis data adalah (1) mengumpulkan data, (2) mereduksi data, (3) menyajikan data, (4) verifikasi, dan (5) penarikan kesimpulan.

Sebanyak 18 responden mahasiswa yang diberikan angket secara acak dengan usia ratarata 21 tahun, dengan rata-rata 3 jumlah akun media sosial, dan rata-rata menggunakan media sosial dalam jangka waktu 46 bulan atau setara 4 tahun, dengan rata-rata durasi akses media sosial +30 menit per akses.

Angket yang didistribusi terdiri dari 16 pernyataan yang meliputi aspek (1) tujuan pemanfaatan media sosial, (2) aktivitas interaksi otentik, (3) aktivitas tekstual ekspresif, dan (4) aktivitas emosional-sosial. Keempat aspek ini dapat dideskripsikan sebagai berikut:

\begin{tabular}{|c|c|c|c|}
\hline No. & Aspek & Tujuan Data & $\begin{array}{l}\text { Poin pada } \\
\text { kuisioner }\end{array}$ \\
\hline 1. & $\begin{array}{l}\text { Tujuan } \\
\text { pemanfaatan media } \\
\text { sosial }\end{array}$ & $\begin{array}{l}\text { Data ini akan menunjukkan } \\
\text { informasi tentang tujuan formal dan } \\
\text { informal pemanfaatan media sosial. }\end{array}$ & $\begin{array}{l}1,2,3,14, \text { dan } \\
15\end{array}$ \\
\hline 2. & $\begin{array}{l}\text { Aktivitas interaksi } \\
\text { otentik }\end{array}$ & $\begin{array}{l}\text { Data ini akan menunjukkan } \\
\text { informasi tentang otentisitas } \\
\text { interaksi yang diasumsikan sebagai } \\
\text { pemicu motivasi menulis di media } \\
\text { sosial. Data ini juga mengandung } \\
\text { informasi tentang interaksi tekstual } \\
\text { seperti memberikan feedback pada } \\
\text { status relasi media sosial. }\end{array}$ & 6,7 dan 10 \\
\hline 3. & $\begin{array}{l}\text { Aktivitas tekstual } \\
\text { ekspresif }\end{array}$ & $\begin{array}{l}\text { Data ini mengandung informasi } \\
\text { tentang aktivitas menulis mahasiswa } \\
\text { untuk mengekspresikan diri, baik } \\
\text { dalam bentuk pembaharuan status } \\
\text { atau pemberian feedback. }\end{array}$ & 4 dan 11 \\
\hline 4. & $\begin{array}{l}\text { Aktivitas } \\
\text { emosional-sosial }\end{array}$ & $\begin{array}{lrr}\text { Data ini mengandung } & \text { informasi } \\
\text { mental } & \text { mahasiswa } & \text { yang } \\
\text { memengaruhi interaksi } & \text { sosial di } \\
\text { media sosial yang mereka } & \text { gunakan. }\end{array}$ & $\begin{array}{l}5,8,9,12,13 \\
\text { dan } 16\end{array}$ \\
\hline
\end{tabular}

\section{Pembahasan}

\subsection{Penyajian Data}

Melalui data angket yang didistribusikan pada 18 mahasiswa secara random, maka peneliti berhasil menjaring data atau informasi sebagaimana yang dapat dilihat dalam tabel di bawah ini: 


\begin{tabular}{|c|c|c|c|c|c|c|}
\hline \multirow[b]{2}{*}{ No. } & \multirow[b]{2}{*}{ Aspek } & \multirow[b]{2}{*}{ Pernyataan } & \multicolumn{4}{|c|}{ Persentase Pilihan } \\
\hline & & & $\begin{array}{l}\text { Sangat } \\
\text { Setuju }\end{array}$ & Setuju & $\begin{array}{c}\text { Kurang } \\
\text { Setuju }\end{array}$ & $\begin{array}{l}\text { Tidak } \\
\text { Setuju }\end{array}$ \\
\hline 1. & \multirow{5}{*}{$\begin{array}{c}\text { Tujuan } \\
\text { Pemanfaatan } \\
\text { Media Sosial }\end{array}$} & $\begin{array}{l}\text { Saya menggunakan media } \\
\text { sosial untuk mendapatkan } \\
\text { informasi formal seperti berita } \\
\text { faktual. }\end{array}$ & $44 \%$ & $56 \%$ & $0 \%$ & $0 \%$ \\
\hline 2. & & $\begin{array}{l}\text { Saya menggunakan media } \\
\text { sosial untuk mengetahui } \\
\text { informasi tentang keberadaan } \\
\text { atau situasi rekan atau } \\
\text { keluarga saya. }\end{array}$ & $56 \%$ & $33 \%$ & $11 \%$ & $0 \%$ \\
\hline 3. & & $\begin{array}{l}\text { Saya menggunakan media } \\
\text { sosial untuk menyampaikan } \\
\text { informasi formal seperti } \\
\text { berita. }\end{array}$ & $22 \%$ & $56 \%$ & $22 \%$ & $0 \%$ \\
\hline 4. & & $\begin{array}{l}\text { Saya biasa mengakses media } \\
\text { sosial di sela-sela kegiatan } \\
\text { lain seperti belajar di kelas } \\
\text { atau belajar di rumah. }\end{array}$ & $17 \%$ & $17 \%$ & $28 \%$ & $39 \%$ \\
\hline 5. & & $\begin{array}{lr}\begin{array}{l}\text { Menurut saya } \\
\text { sangat }\end{array} & \text { media sosial } \\
\text { perkembantu } \\
\text { saya. }\end{array}$ & $50 \%$ & $39 \%$ & $11 \%$ & $0 \%$ \\
\hline 6. & \multirow{3}{*}{$\begin{array}{l}\text { Aktivitas } \\
\text { Interaksi } \\
\text { Otentik }\end{array}$} & $\begin{array}{l}\text { Saya selalu menggunakan } \\
\text { media sosial sebagai media } \\
\text { tukar informasi karena saya } \\
\text { percaya pada rekan atau } \\
\text { keluarga saya di media sosial. }\end{array}$ & $11 \%$ & $39 \%$ & $33 \%$ & $17 \%$ \\
\hline 7. & & $\begin{array}{l}\text { Saya adalah anggota grup } \\
\text { tertentu di media sosial dan } \\
\text { saya aktif memberikan } \\
\text { informasi atau mengomentari } \\
\text { informasi di grup-grup } \\
\text { tersebut. }\end{array}$ & $6 \%$ & $50 \%$ & $39 \%$ & $6 \%$ \\
\hline 8. & & $\begin{array}{l}\text { Saya selalu mengomentari } \\
\text { status orang yang saya kenal } \\
\text { dan komentar saya selalu } \\
\text { relevan dengan statusnya. }\end{array}$ & $11 \%$ & $28 \%$ & $33 \%$ & $28 \%$ \\
\hline 9. & \multirow{2}{*}{$\begin{array}{l}\text { Aktivitas } \\
\text { Tekstual } \\
\text { Ekspresif }\end{array}$} & $\begin{array}{l}\text { Saya menggunakan media } \\
\text { sosial untuk memberitahukan } \\
\text { pemikiran saya tentang } \\
\text { sesuatu. }\end{array}$ & $17 \%$ & $50 \%$ & $33 \%$ & $0 \%$ \\
\hline 10. & & $\begin{array}{l}\text { Saya selalu meng-update } \\
\text { status terbaru setiap kali saya } \\
\text { mengakses media sosial. }\end{array}$ & $0 \%$ & $39 \%$ & $44 \%$ & $17 \%$ \\
\hline 11. & \multirow{3}{*}{$\begin{array}{l}\text { Aktivitas } \\
\text { Emosional } \\
\text { Sosial }\end{array}$} & $\begin{array}{l}\text { Saya menggunakan media } \\
\text { sosial untuk mengekspresikan } \\
\text { perasaan saya terhadap } \\
\text { sesuatu. }\end{array}$ & $6 \%$ & $44 \%$ & $28 \%$ & $22 \%$ \\
\hline 12. & & $\begin{array}{l}\text { Saya selalu mengecek apakah } \\
\text { ada yang mengomentari atau } \\
\text { me-like status saya di media } \\
\text { sosial. }\end{array}$ & $6 \%$ & $72 \%$ & $11 \%$ & $11 \%$ \\
\hline 13. & & Saya suka berbagi informasi & $17 \%$ & $56 \%$ & $22 \%$ & $6 \%$ \\
\hline
\end{tabular}

Gramatika, Volume IV, Nomor 2, Juli-Desember 2016 


\begin{tabular}{|c|c|c|c|c|c|}
\hline & $\begin{array}{l}\text { yang bermanfaat dengan } \\
\text { menggunakan tombol share. }\end{array}$ & & & & \\
\hline 14. & $\begin{array}{l}\text { Saya senang membuka } \\
\text { kembali informasi atau status- } \\
\text { status lama yang pernah saya } \\
\text { tuliskan di media sosial. }\end{array}$ & $22 \%$ & $39 \%$ & $33 \%$ & $6 \%$ \\
\hline 15. & $\begin{array}{l}\text { Saya selalu mengkonfirmasi } \\
\text { permintaan pertemanan } \\
\text { seseorang di media sosial } \\
\text { meskipun orang tersebut tidak } \\
\text { saya kenali sebelumnya. }\end{array}$ & $22 \%$ & $28 \%$ & $22 \%$ & $28 \%$ \\
\hline 16. & $\begin{array}{l}\text { Saya senang ketika nama saya } \\
\text { dicantumkan (di-tag) dalam } \\
\text { status seseorang. }\end{array}$ & $11 \%$ & $28 \%$ & $33 \%$ & $28 \%$ \\
\hline
\end{tabular}

\subsection{Interpretasi Data}

Untuk menyediakan pembacaan data, peneliti telah melakukan merging komponen angket sesuai dengan aspek-aspek dan menemukan rata-rata persentase tiap pilihan sebagaimana yang ditampilkan pada tabel berikut:

\begin{tabular}{|c|c|c|c|c|c|c|}
\hline \multirow[b]{2}{*}{ No. } & \multirow[b]{2}{*}{ Aspek } & \multirow[b]{2}{*}{ Pernyataan } & \multicolumn{4}{|c|}{ Rerata Persentase Pilihan } \\
\hline & & & $\begin{array}{l}\text { Sangat } \\
\text { Setuju }\end{array}$ & Setuju & $\begin{array}{c}\text { Kurang } \\
\text { Setuju }\end{array}$ & $\begin{array}{c}\text { Tidak } \\
\text { Setuju }\end{array}$ \\
\hline 1. & 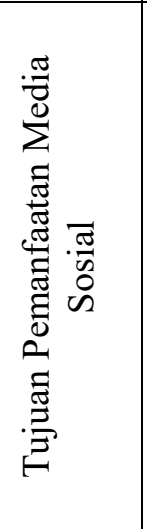 & $\begin{array}{l}\text { Media sosial adalah media } \\
\text { bertukar informasi baik } \\
\text { formal maupun non-formal } \\
\text { yang digunakan untuk } \\
\text { membagi dan menerima } \\
\text { informasi kapan saja dan } \\
\text { dimana saja untuk menambah } \\
\text { pengetahuan } \\
\text { mengembangkan kemampuan } \\
\text { diri melalui informasi- } \\
\text { informasi tersebut. }\end{array}$ & $38 \%$ & $40 \%$ & $14 \%$ & $8 \%$ \\
\hline 2. & 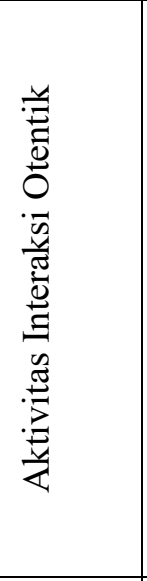 & \begin{tabular}{lr}
\multicolumn{2}{l}{ Relasi di media sosial adalah } \\
relasi otentik yang dapat \\
dipercaya & dan \\
bertanggungjawab & atas \\
informasi-informasi & yang \\
dibagikan. Media & sosial \\
merupakan wadah interaksi & \\
otentik manusia dari berbagai \\
kalangan \\
memungkinkan yang \\
komunikasi tulis \\
otentik.
\end{tabular} & $9 \%$ & $39 \%$ & $35 \%$ & $17 \%$ \\
\hline 3. & 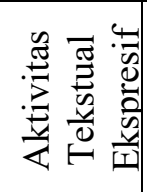 & $\begin{array}{l}\text { Media sosial adalah fasilitas } \\
\text { untuk mengekspresikan } \\
\text { pemikiran yang efektif. }\end{array}$ & $9 \%$ & $45 \%$ & $39 \%$ & $9 \%$ \\
\hline
\end{tabular}




\begin{tabular}{|c|c|c|c|c|c|c|}
\hline 4. & 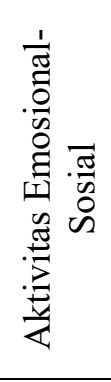 & $\begin{array}{lr}\text { Penggunaan media } & \text { sosial } \\
\text { dipengaruhi oleh } & \text { aspek } \\
\text { emosional baik dari segi } & \text { dividu, } \\
\text { keterlibatan } & \text { individu } \\
\text { transaksi } & \text { informasi } \\
\text { tertulis,ekspresi emosional, } \\
\text { maupun dari segi konstruksi } \\
\text { sosial. }\end{array}$ & $14 \%$ & $45 \%$ & $25 \%$ & $17 \%$ \\
\hline
\end{tabular}

\subsection{Interpretasi Data Berdasarkan Aspek}

Tidak dapat dipungkiri bahwa data yang ditampilkan di dalam tabel di atas sangat bervariasi. Data-data di atas menunjukkan adanya variabilitas sebab media sosial memiliki pengaruh yang cukup kuat terhadap aktivitas menulis mahasiswa dibandingkan dengan aktivitas menulis di ruang-ruang kelas.

Pada aspek pertama, terlihat bahwa para mahasiswa (khususnya sampel penelitian ini) memberikan nilai positif terhadap media sosial terutama menjadikannya sebagai media transaksi informasi yang bertanggungjawab. $38 \%$ mahasiswa sangat setuju dan $40 \%$ mahasiswa setuju dengan hal tersebut. Data ini sepertinya sesuai dengan gagasan Urkuhart \& McIver (2005) dalam hal terjadinya interaksi kolaboratif dalam pengertian terjadinya pengayaan informasi untuk pengembangan pengetahuan, wawasan, dan kemampuan. Sebagian besar mahasiswa antusias menggunakan media sosial karena tujuan dan manfaat yang dapat mereka peroleh dari media sosial dan ini sejalan dengan teori motivasi Deci, Vallerand, Pelletier \& Ryan (1995) yang menyatakan bahwa kebutuhan terhadap tujuan yang menjadi pemicu motivasi. Dengan kata lain, mereka beranggapan bahwa media sosial adalah sumber informasi. Dengan anggapan atau pemberian makna positif terhadap media sosial seperti ini, maka teori emosi Fridja (1988) menemukan pembenaran. Para mahasiswa sangat termotivasi untuk terlibat dalam relasi media sosial karena makna dan nilai yang mereka berikan terhadap media sosial di dalam struktur pengalaman dan kehidupan mereka.

Pada aspek kedua, terlihat bahwa gagasan writingmatrix yang dibangun oleh Stevens dan rekan-rekannya (2008) mendapatkan tantangan dari data di atas. Data penelitian ini menunjukkan bahwa otentisitas komunikator, atau person yang berkomunikasi melalui media sosial belum tentu menjadi pemicu antusiasme mereka. Sebagian besar mahasiswa yang menggunakan media sosial tidak peduli dengan otentisitas pembagi informasi. Hal ini menjadi logis ketika kita menyadari sebagian besar orang yang berkiprah di media sosial tidak menampilkan identitas orisinil mereka. Meskipun informasi yang mereka bagikan adalah informasi yang bertanggungjawab, hal tersebut sama sekali tidak berhubungan dengan identitas orisinil mereka.

Pada aspek ketiga, data menunjukkan bahwa sebagian besar mahasiswa menggunakan media sosial untuk menyampaikan gagasan mereka. Namun angka persentase kurang setuju (39\%) dan tidak setuju (9\%) layak mendapatkan perhatian. Temuan ini memberi kesan seolaholah sebagian mahasiswa lebih cenderung bersikap pasif (menerima informasi) dari pada bersikap aktif (memberikan informasi). Persentase setuju (45\%) menunjukkan bahwa sebagian besar mahasiswa menggunakan media sosial untuk menyampaikan informasi secara tertulis. Meskipun demikian, kita patut menyadari media sosial yang dominan seperti facebook merupakan media sosial yang bersifat multimedia. Penggunaannya tidak hanya memiliki fitur teks tetapi juga audio-visual. Ada kemungkinan bahwa mahasiswa tertarik dengan fitur-fitur audio-visual media sosial yang kemudian menekan kecenderungan aktivitas interaksi tekstual mereka.

Pada aspek keempat, data menunjukkan bahwa emosi memainkan peranan yang cukup penting dalam konstruksi relasi sosial virtual di media-media sosial. Para mahasiswa terlibat secara emosional dalam menggunakan media sosial ini, baik dari segi transaksi informasi maupun segi konstruksi sosial. Aspek emosional inilah yang kemudian memicu motivasi untuk bergelut sepanjang hari dengan media sosial, baik secara intrinsik maupun secara ekstrinsik. 
Otentisitas komunikator, sebagaimana yang digagas melalui proyek writingmatrix, menyimpulkan bahwa interaksi otentik melalui media tertentu (termasuk media sosial) merupakan salah satu pemicu motivasi menulis mahasiswa. Kecenderungan mahasiswa untuk beranggapan bahwa tulisan mereka dibaca oleh pembaca otentik merupakan trigger antusiasme mereka. Penelitian ini tidak serta-merta membantah kesimpulan writingmatrix tersebut. Hanya saja, penelitian ini menemukan bahwa makna dan nilai yang diberikan oleh mahasiswa terhadap aktivitas menulis di media sosial yang merupakan pemicu utama antusiasme mereka.

Fitur-fitur yang disediakan oleh media sosial, kepuasan-kepuasan emosional yang didapatkan, serta tujuan-tujuan yang dicapai melalui pemanfaatan media sosial memainkan peranan penting dalam pemberian makna dan nilai terhadap media sosial ini. Sesuai dengan teori emosi Fridja (1988), Cacciopo \& Berntson (2007) dan teori motivasi Bold (2004), Dickinson (1995), dan lain sebagainya, nilai dan makna media sosial inilah yang menjadi pemicu motivasi, bukan otentisitas.

Informasi dari penelitian ini akhirnya memberikan kita gambaran untuk menjawab mengapa pembelajaran menulis (writing) di ruang-ruang kelas menjadi sangat menantang bagi mahasiswa. Hal tersebut disebabkan oleh nilai dan makna yang mereka berikan terhadap aktivitas menulis di ruang-ruang kelas berbeda dengan nilai dan makna yang mereka berikan terhadap aktivitas menulis di media-media sosial. Ini berkaitan dengan fitur-fitur yang kita sediakan untuk mempermudah aktivitas mereka (sesuai gagasan Lee, 2008) dan memuaskan kebutuhan emosional mereka (sesuai gagasan Frijda, 1998). Selama hal-hal ini tidak terpenuhi, sangat jelas bahwa masalah minimnya motivasi menulis mahasiswa di ruang-ruang kelas akan diperpanjang dari waktu ke waktu.

\section{Simpulan dan Saran}

Peneliti menyimpulkan bahwa otentisitas komunikator bukanlah pemicu utama motivasi menulis mahasiswa di media-media sosial. Pemicu utama motivasi dan antusiasme mahasiswa khususnya aktivitas menulis mereka di media-media sosial adalah fitur-fitur yang disediakan oleh media sosial yang dapat menyampaikan mereka pada tujuan pemanfaatan media sosial tersebut, media sosial sebagai wadah untuk mengekspresikan pemikiran, dan untuk memenuhi kepuasan emosional dalam konstruksi sosial virtual. Semua pemicu ini bermuara pada pernyataan bahwa nilai dan makna yang diberikan oleh mahasiswa kepada media sosial inilah yang membentuk emosi dan motivasi para mahasiswa terhadap media sosial. Hal demikian juga turut menjelaskan penyebab minimnya motivasi menulis mahasiswa di ruang-ruang kelas yang menyebabkan maraknya plagiarisme dan bisnis tugas akhir di dalam dunia akademik. Seandainya para dosen pengasuh mata kuliah menulis (writing) di perguruan tinggi mampu membimbing mahasiswa memberikan makna dan nilai yang positif terhadap aktivitas menulis di ruang kelas sebagai suatu aktivitas linguistis yang realistis dan tidak terisolasi dari kehidupan nyata mahasiswa, maka peluang untuk menumbuh-kembangkan motivasi menulis mahasiswa menjadi lebih besar.

Sebagai suatu riset mini, penelitian ini disadari masih membutuhkan pengembangan dari segi sampel dan instrumen. Meskipun penelitian ini menghasilkan simpulan dengan batasan yang tegas, namun penelitian pengembangan masih tetap dibutuhkan. Oleh karena itu, disarankan untuk peneliti lain untuk melakukan penelitian dengan tema yang serupa namun pada sampel dan instrumen yang lebih berkembang.

\section{Daftar Pustaka}

Bold, C. 2004. Supporting Learning and Teaching. David Fulton Publisher Ltd.

Cacioppo, J. T. And Berntson, G. G. 2007. Affective Distinctiveness: Illusory or Real? Cognition \& Emotion, 21: 6, 1347-1359

Deci, E.L., Vallerand, R. J., Pelletier, L. G., and Ryan, R.M. 1995. Motivation and Education: The Self-Determination Perspective. Educational Psychologist, 26 (3\&4), pp.325-346.

Dickinson, L. 1995. Autonomy and Motivation: A Literature Review. System. Vol. 23, No. 2, pp. 165-174 
Frijda, N. H. 1988. The Laws of Emotion. American Psychological Association. May, 1988. Vol. 43, No. 5, pp.349-358

Hong, F. 2006. Students' Perception of Peer Response Activity in English Writing Instruction. CELEA (Bimonthly) Aug. 2006. Vol. 29, No. 4

Lee, M. J. 2008. Using Blogs as ePortfolios in ESL/EFL Writing Classes. The Newsletter of TESOL's Second Language Writing Interest Section. 2008. Vol.3 No. 2

Lewis, M., Jones, J. M. H., and Barrett, L.F. 2008. Handbook of Emotions. The Guilford Press

Noback, et al. 2005. The Human Nervous System: Structure and Function. Sixth Edition. Humana Press.
Pinkman, K. 2005. Using Blogs in the Foreign Language Classroom: Encouraging Learner Independence. The JALT CALL Journal, 2005, Vol. I, No. I, pp.12-24.

Ryan, R.M., and Deci, E.L. 2000. Intrinsic and Extrinsic Motivation: Classic Definitions and New Directions. Contemporary Educational Psychology. 25, pp. 54-67 (2000).

Stevens, et al. 2008. Writingmatrix: Connecting Students with Blogs, Tags, and Social Networking. TESL-EJ. March 2008, Vol. 11, No. 4

Urkuhart, V dan McIver, M. 2005. Teaching Writing in Content Areas. McREL.

Williams, J. 2005. Teaching Writing in Second and Foreign Language Classroom. McGrawHill. 